\title{
Asthma, allergy, and atopy in three south-east Asian populations
}

\author{
Roland Leung, Philip Ho
}

\begin{abstract}
Background - Whilst many recent reports have suggested a rise in the prevalence of asthma and allergic disease in Western countries, little is known about the epidemiology of these common conditions in south-east Asia. This study compared the prevalence of asthma and allergic disease amongst secondary school students in three south-east Asian populations - Hong Kong, Kota Kinabalu in Malaysia, and San $\mathrm{Bu}$ in China - and investigated the associations with atopy and family history. Methods - Secondary school students were given standard questionnaires on respiratory and allergic symptoms for completion by parents with response rates of $89.2 \%$ in Hong Kong (611 male, 451 female; mean (SD) age $=13.9(1.8$ years), $87.6 \%$ in Kota Kinabalu (134 male, 275 female; $15 \cdot 5$ $(2 \cdot 1)$ years), and $98.6 \%$ in San Bu (492 male, 245 female; $16 \cdot 4$ (1.8) years). Skin tests were performed in a subsample of
\end{abstract} students to determine atopic status.

Results - The respective prevalence (and $\mathbf{9 5 \%}$ CI) for hayfever, eczema, and wheeze or asthma were $15 \cdot 7 \%(13 \cdot 5,17 \cdot 9), 20 \cdot 1 \%$ $(17 \cdot 7,22 \cdot 5), 11 \cdot 6 \%(9 \cdot 3,13 \cdot 9)$ in Hong Kong, $11 \cdot 2 \%(8 \cdot 2,14 \cdot 3), 7 \cdot 6 \%(5 \cdot 0,10 \cdot 1), 8 \cdot 2 \%(5 \cdot 5$, $10 \cdot 9)$ in Kota Kinabalu, and $2 \cdot 1 \%(1 \cdot 2,3 \cdot 1)$, $7 \cdot 2 \%(5 \cdot 4,9 \cdot 1), 1 \cdot 9 \%(0 \cdot 7,3 \cdot 1)$ in San Bu. Atopy was common and was present in $49 \cdot 0-63.9 \%$ of subjects in the three populations. Dust mite and cockroach were the commonest allergens that gave positive reactions in $42 \cdot 8-60 \cdot 5 \%$ and $25 \cdot 7-35 \cdot 9 \%$ of students respectively. A higher proportion of students in Hong Kong had severe degree of reactivity on skin test than the other two populations. Family history was associated with asthma and allergic symptoms in the three populations conferring a 3-80-fold increase in risk to family members and was a stronger predictor for asthma and allergy than atopy.

Conclusions-Prevalence of asthma and allergic disease is low compared with Western countries, but considerable differences exist between the three south-east Asian populations despite similar rates of atopy. Asthma and allergic disease are more strongly associated with family history than atopy, which suggests that genetic and environmental factors common to the family, other than aeroallergen sensitisation, are important in the pathogenesis of asthma and allergy in the region.

(Thorax 1994;49:1205-1210)
The prevalence of a history of wheeze and asthma in children ranges from $11.9 \%$ to $23.1 \%$ in Western countries. ${ }^{1-3}$ Recent studies have shown that the prevalence of asthma has been increasing in both children ${ }^{3-5}$ and adults. ${ }^{6}$ Some of the reasons proposed for the increase in asthma prevalence include heightened community awareness of asthma symptoms, a change in diagnostic labelling patterns amongst health professionals, and increase in the severity of illness amongst the same number of asthmatics thus enhancing awareness of symptoms. The parallel increase in the prevalence of hayfever ${ }^{56}$ and eczema ${ }^{6}$ suggests a more broadly based change in reactivity, possibly due to increased exposure to allergens and other environmental factors.

There are a few studies on the prevalence of asthma and allergic disease in Asian Pacific countries, but the available data suggest that these conditions are much less common than in Western countries. ${ }^{7-9} \mathrm{~A}$ recent report by Leung and Jenkins based on the current study showed that the prevalence of respiratory and allergic symptoms was low in Chinese school students despite a high prevalence of atopy. ${ }^{10}$ Nevertheless, an increase in asthma prevalence in the region has also been reported over the last two decades. ${ }^{11}$ The lack of uniformity in methodology and a reliable "gold standard" for defining asthma makes it difficult to compare prevalence data between studies. We have examined the prevalence of asthma and allergic disease in school students in three separate south-east Asian populations using identical methodology, and have investigated the associations with sensitisation to environmental aeroallergens and family history.

\section{Methods}

SUBJECTS

Permission was obtained from local authorities to conduct the study in the region and a number of secondary schools in each population were assigned to the study. Within each school every second class in each grade was selected and all students in the selected classes were enrolled for the study. All students were of ethnic Chinese background (in Malaysia students of Malay and Indian extract were excluded). The geographical locations of the three study populations are shown in the figure. Hong Kong is a metropolitan city with a population of six million and has a subtropical climate. San Bu has a population of 144000 and is situated $140 \mathrm{~km}$ south west of Guangzhou, the provincial capital of Guangdong, and $200 \mathrm{~km}$ west of Hong Kong. It has a similar climate to 


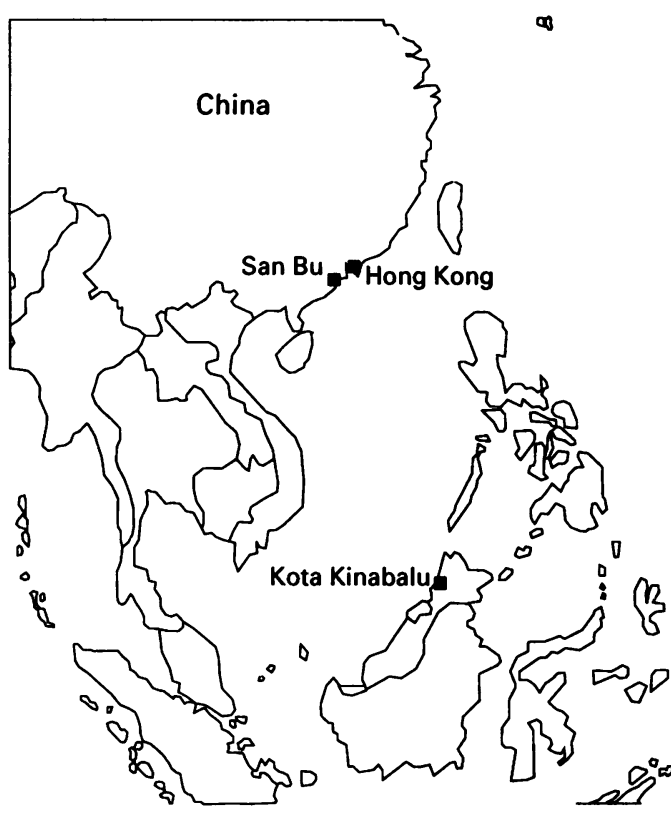

Geographical locations of the three study populations

Hong Kong. Kota Kinabalu is situated on the northern coast of the Island of Borneo and has a tropical climate with a population of 250000 . The study was performed between April and June 1992 with a temperature range of $25-28^{\circ} \mathrm{C}$ and relative humidity of $70-90 \%$.

\section{QUESTIONNAIRE}

Questions on respiratory and allergic symptoms were from standard respiratory questionnaires. ${ }^{1112}$ These were appropriately translated into Chinese and the Chinese version of the questionnaire has previously been used in epidemiological studies in the region. ${ }^{1314}$ Hayfever or seasonal allergic rhinitis was defined as itchy, runny nose associated with paroxysms of sneezing and itchy, runny eyes in spring and summer. Eczema was defined as an itchy, red rash in the crease of elbows and bends of knees. Wheezing was defined as a whistling noise in the chest on breathing. The presence of asthma was indicated by an affirmative response to the question: "Have you ever had asthma?" A history of wheeze or asthma ever is used as a more accurate measure of the "asthma syndrome".

Table 1 Responses to questionnaire survey

\begin{tabular}{|c|c|c|c|}
\hline & $\begin{array}{l}\text { Hong Kong } \\
(n=1062)\end{array}$ & $\begin{array}{l}\text { Kota Kinabalu } \\
(n=409)\end{array}$ & $\begin{array}{l}\text { San } B u \\
(n=737)\end{array}$ \\
\hline Response rate (\%) & $89 \cdot 2$ & $87 \cdot 6$ & $98 \cdot 6$ \\
\hline $\begin{array}{l}\text { Male } \\
\text { Female }\end{array}$ & $\begin{array}{l}611 \\
451\end{array}$ & $\begin{array}{l}134 \\
275\end{array}$ & $\begin{array}{l}492 \\
245\end{array}$ \\
\hline Mean (SD) age (years) & $13.9(1.8)$ & $15 \cdot 5(2 \cdot 1)$ & $16 \cdot 4(1 \cdot 8)$ \\
\hline $\begin{array}{l}\text { Prevalence }(95 \% \mathrm{CI}) \text { of } \\
\text { symptoms } \\
\text { (standardised by age and sex) } \\
\text { Hayfever } \\
\text { Eczema } \\
\text { Wheeze ever } \\
\text { Wheeze in past } 12 \text { months } \\
\text { Asthma ever } \\
\text { Wheeze or asthma ever }\end{array}$ & $\begin{array}{c}15 \cdot 7(13 \cdot 5,17 \cdot 9) \\
20 \cdot 1(17 \cdot 7,22 \cdot 5) \\
7 \cdot 8(6 \cdot 2,9 \cdot 4) \\
3 \cdot 7(2 \cdot 6,4 \cdot 8) \\
6 \cdot 6(5 \cdot 1,8 \cdot 1) \\
11 \cdot 6(9 \cdot 3,13 \cdot 9)\end{array}$ & $\begin{array}{c}11 \cdot 2(8 \cdot 2,14 \cdot 3) \\
7 \cdot 6(5 \cdot 0,10 \cdot 1) \\
7 \cdot 7(5 \cdot 1,10 \cdot 2) \\
4 \cdot 9(2 \cdot 8,7 \cdot 0) \\
3 \cdot 3(1 \cdot 6,5 \cdot 0) \\
8 \cdot 2(5 \cdot 5,10 \cdot 9)\end{array}$ & $\begin{array}{l}2 \cdot 1(1 \cdot 1,3 \cdot 1) \\
7 \cdot 2(5 \cdot 4,9 \cdot 1) \\
1.9(0 \cdot 7,3 \cdot 1) \\
1 \cdot 1(0 \cdot 2,2 \cdot 0) \\
1.6(0 \cdot 5,2 \cdot 7) \\
1.9(0 \cdot 7,3 \cdot 1)\end{array}$ \\
\hline
\end{tabular}

\section{SKIN TEST}

In Kota Kinabalu and San Bu all questionnaire respondents were asked to undergo a skin test but only half of the respondents in Hong Kong were randomly selected for the test. Skin tests were performed according to Pepys' method ${ }^{15}$ using histamine $(10 \mathrm{mg} / \mathrm{ml})$ and normal saline as positive and negative controls respectively. Nine common aeroallergens were used which were grouped into five allergen groups: (1) pollen - rye grass (Lolium perenne), couch grass (Cynodon dactylon), seven grass mix (Kentucky blue, orchard, redtop, timothy, sweet vernal, meadow fescue, perennial rye); (2) dust mite (Dermatophagoides pteronyssinus); (3) mould (mixture of Alternaria, Aspergillus, Hormodendrum, and Penicillium); (4) cockroach (mixture of American, German and Oriental spp); (5) animal dander (cat, dog, and rat hair). Weals of $3 \mathrm{~mm}$ or greater were regarded as positive in the absence of a reaction to normal saline and subjects with one or more positive reactions were considered atopic. Each subject was assigned a reactivity index according to both the number and the size of the positive skin test reaction as described by Peat et al. ${ }^{16}$ This integer index was the sum of the number of the five allergen groups that gave a positive reaction plus the size of the largest reaction (1 for $<4 \mathrm{~mm}, 2$ for $\geqslant 4 \mathrm{~mm}$ ). Non-atopic subjects had a reactivity index of zero by definition and, for the purpose of simplicity, an index of 2 and 3 was defined as mild reactivity, 4 or 5 as moderate reactivity, and 6 or 7 as severe reactivity.

\section{STATISTICAL ANALYSIS}

The statistical package Epi-Info was used to categorise and analyse the data. ${ }^{17} \chi^{2}$ for trend in proportion was used to compare the prevalence of symptoms and degree of reactivity between the three populations. Relationships between asthma and allergic disease and explanatory variables - age, sex, atopic status, and family history (at least one parent and/or sibling) - were analysed by multiple logistic regression using the statistical package EGRET. ${ }^{18}$ Age was treated as a categorical variable (11-13 years, 14-16 years, and 17-20 years) with the 11-13 year group as the baseline. All other explanatory variables were treated as binary factors, the baseline corresponding to being unaffected (or being female for the sex variable). Estimates of odds ratios, standard errors, and confidence intervals were based on asymptotic likelihood theory. A significance level of $p<0.05$ was used.

\section{Results}

Table 1 shows the response to the questionnaire. The response rates were satisfactory in all three study populations with an overall rate of $90 \%$. There were twice as many boys as girls in San $\mathrm{Bu}$, whereas the opposite sex distribution was seen in Kota Kinabalu. Subjects in San Bu were older than those in Kota Kinabalu and Hong Kong and the difference in mean age was significant $(p<0 \cdot 01$, Kruskal- 
Table 2 Skin test reactivity in the three study populations. Values are percentage (95\% CI)

\begin{tabular}{|c|c|c|c|}
\hline & $\begin{array}{l}\text { Hong Kong } \\
(n=471)\end{array}$ & $\begin{array}{l}\text { Kota Kinabalu } \\
(n=321)\end{array}$ & $\begin{array}{l}\text { San Bu } \\
(n=647)\end{array}$ \\
\hline Response rate & $88 \cdot 7$ & $78 \cdot 5$ & $78 \cdot 8$ \\
\hline $\begin{array}{l}\text { Pollen } \\
\text { Grass mix } \\
\text { Rye } \\
\text { Couch }\end{array}$ & $\begin{array}{l}2 \cdot 1 \\
2 \cdot 1 \\
4 \cdot 5\end{array}$ & $\begin{array}{r}2 \cdot 8 \\
4 \cdot 1 \\
16 \cdot 3\end{array}$ & $\begin{array}{l}3 \cdot 7 \\
4 \cdot 3 \\
3 \cdot 1\end{array}$ \\
\hline $\begin{array}{l}\text { Mite } \\
\quad \text { D pteronyssinus }\end{array}$ & $55 \cdot 5$ & $60 \cdot 5$ & $42 \cdot 8$ \\
\hline $\begin{array}{l}\text { Mould } \\
\text { Mould mix }\end{array}$ & $23 \cdot 4$ & $8 \cdot 2$ & $2 \cdot 0$ \\
\hline $\begin{array}{l}\text { Cockroach } \\
\text { Cockroach mix }\end{array}$ & $25 \cdot 7$ & $30 \cdot 7$ & $35 \cdot 9$ \\
\hline $\begin{array}{l}\text { Animal } \\
\text { Cat hair } \\
\text { Dog hair } \\
\text { Rat epithelia }\end{array}$ & $\begin{array}{r}10 \cdot 4 \\
2 \cdot 3 \\
2 \cdot 8\end{array}$ & $\begin{array}{l}3 \cdot 1 \\
2 \cdot 5 \\
3 \cdot 4\end{array}$ & $\begin{array}{l}0 \cdot 3 \\
0 \cdot 8 \\
0 \cdot 8\end{array}$ \\
\hline $\begin{array}{l}\text { Allergen groups } \\
\text { Pollen } \\
\text { Mite } \\
\text { Mould } \\
\text { Cockroach } \\
\text { Animal }\end{array}$ & $\begin{array}{c}6 \cdot 4(4 \cdot 2,8 \cdot 6) \\
55 \cdot 5(51 \cdot 0,60 \cdot 0) \\
23 \cdot 4(19 \cdot 6,27 \cdot 2) \\
25 \cdot 7(21 \cdot 8,29 \cdot 6) \\
12 \cdot 6(9 \cdot 6,16 \cdot 0)\end{array}$ & $\begin{aligned} 17 \cdot 2 & (13 \cdot 1,21 \cdot 3) \\
60 \cdot 5 & (55 \cdot 2,65 \cdot 8) \\
8 \cdot 2 & (5 \cdot 2,11 \cdot 2) \\
30 \cdot 7 & (25 \cdot 7,35 \cdot 7) \\
9 \cdot 1 & (6 \cdot 0,12 \cdot 2)\end{aligned}$ & $\begin{array}{c}5.6(3 \cdot 8,7 \cdot 4) \\
42.8(39 \cdot 0,46 \cdot 6) \\
2.0(0.9,3 \cdot 1) \\
35.9(32 \cdot 2,39 \cdot 6) \\
1.9(0.8,3.0)\end{array}$ \\
\hline $\begin{array}{l}\text { Atopy } \\
\geqslant 1+\text { ve skin test }\end{array}$ & $57 \cdot 7(53 \cdot 2,62 \cdot 2)$ & $63 \cdot 9(58 \cdot 6,69 \cdot 2)$ & $49 \cdot 0(45 \cdot 2,52 \cdot 9)$ \\
\hline
\end{tabular}

Wallis one way analysis of variance). Because of the age and sex difference the prevalence data in table 1 were adjusted for these two variables. In general, the prevalence of allergic disease was highest in Hong Kong and lowest in San $\mathrm{Bu}(\mathrm{p}<0.05)$. However, the prevalence of eczema was similar between Kota Kinabalu and San Bu whilst a history of wheeze was as common in Hong Kong as in Kota Kinabalu.

Table 2 shows the skin test reactivity pattern in the three populations. The age and sex distribution of subjects who underwent skin testing was similar to that for the questionnaire survey. Atopy was common and was present in $49-63.9 \%$ of students. Dust mite was the commonest allergen that gave positive skin reactions in all three populations, but a higher proportion of students in Kota Kinabalu (60.5\%, 95\% CI 55.2 to $65 \cdot 8)$ was sensitised to dust mite than in San $\mathrm{Bu}(42.8 \%, 95 \% \mathrm{CI}$ 39.0 to $46 \cdot 6, \mathrm{p}<0 \cdot 01)$. Cockroach allergy was also common affecting $25 \cdot 7-35 \cdot 9 \%$ of students. Sensitivity to mould and cat allergens was more frequently encountered in Hong Kong and was uncommon in Kota Kinabalu and San Bu. Positive skin reactions to grass pollen were rare in all three populations with the exception of sensitivity to couch grass which was present in $16 \cdot 3 \%(95 \%$ CI $11 \cdot 5$ to $21 \cdot 1)$ of subjects in Kota Kinabalu.
Over $85 \%$ of atopic students had a mild or moderate degree of reactivity in all three populations, but the proportion of those with severe reactivity was significantly higher in Hong Kong (14.4\%) than in Kota Kinabalu $(10.3 \%)$ or San $\mathrm{Bu}(2.5 \%)(\mathrm{p}<0.001$ for trend in proportion).

Family history was found to be a very strong predictor for hayfever, eczema, and wheeze or asthma ever in all three populations. Table 3 shows that subjects with a family history of asthma and allergy were 3-5 times more likely to have similar symptoms themselves than those with a negative family history. Familial aggregation of asthma and allergic symptoms was particularly evident in San Bu where family history conferred a 17-75-fold increase in risk of similar symptoms in the students. In contrast, atopy was not significantly associated with any allergic symptoms in San Bu. Atopy predicted a history of hayfever and wheeze or asthma ever but not eczema in Kota Kinabalu and Hong Kong.

\section{Discussion}

It is difficult to compare disease prevalence between different populations if there is no uniformity of methodology. We have attempted to overcome this problem by estimating the prevalence of asthma, allergic disease, and atopy in secondary school students of similar age in Hong Kong, Kota Kinabalu, and San $\mathrm{Bu}$ by using identical questionnaire and skin test reagents. Although there is no gold standard for defining asthma, standard respiratory questionnaires have provided a useful estimation of asthma prevalence in the past. ${ }^{19}$ Bronchial hyperresponsiveness was not tested because it was logistically prohibitive in China and Malaysia and, although it would provide an objective measure supportive of the diagnosis of asthma, it lacks both sensitivity and specificity. ${ }^{20}$

Secondary school students were chosen for the study as most children of this age group are expected to be attending schools. The number not at school because of debilitating asthma and allergic disease is likely to be small. Because subjects were sampled in their class groups in the assigned schools and not randomly in the communities, it is possible that the standard errors of estimates could be undervalued if no adjustment for cluster sampling was made. However, as the total number of students at-

Table 3 Relation between asthma and allergic symptoms and selected risk factors

\begin{tabular}{|c|c|c|c|c|c|c|}
\hline \multirow[t]{2}{*}{ Symptoms } & \multicolumn{3}{|c|}{ Atopic status } & \multicolumn{3}{|c|}{ Family history } \\
\hline & $\begin{array}{l}\text { Atopic } \\
(\%)\end{array}$ & $\begin{array}{l}\text { Non-atopic } \\
(\%)\end{array}$ & $\begin{array}{l}\text { Adjusted odds } \\
\text { ratio }(95 \% \mathrm{CI})^{*}\end{array}$ & $\begin{array}{l}\text { Positive } \\
(\%)\end{array}$ & $\begin{array}{l}\text { Negative } \\
(\%)\end{array}$ & $\begin{array}{l}\text { Adjusted odds } \\
\text { ratio ) } 95 \% \text { CI)* }\end{array}$ \\
\hline $\begin{array}{l}\text { Hayfever } \\
\text { Hong Kong } \\
\text { Kota Kinabalu } \\
\text { San Bu }\end{array}$ & $\begin{array}{r}23 \cdot 6 \\
14 \cdot 2 \\
1 \cdot 9\end{array}$ & $\begin{array}{r}10 \cdot 0 \\
5 \cdot 2 \\
1 \cdot 2\end{array}$ & $\begin{array}{l}4 \cdot 0(2 \cdot 1,7 \cdot 5) \\
3 \cdot 0(1 \cdot 2,8 \cdot 0) \\
1.6(0 \cdot 4,5 \cdot 9)\end{array}$ & $\begin{array}{l}41 \cdot 9 \\
39 \cdot 3 \\
23 \cdot 1\end{array}$ & $\begin{array}{l}9 \cdot 6 \\
4 \cdot 2 \\
1 \cdot 2\end{array}$ & $\begin{array}{l}12 \cdot 6(6 \cdot 9,23 \cdot 0) \\
10 \cdot 0(4 \cdot 0,25 \cdot 0) \\
17 \cdot 0(3 \cdot 1,92 \cdot 1)\end{array}$ \\
\hline $\begin{array}{l}\text { Wheeze or asthma } \\
\text { Hong Kong } \\
\text { Kota Kinabalu } \\
\text { San Bu }\end{array}$ & $\begin{array}{r}17 \cdot 0 \\
9 \cdot 3 \\
3 \cdot 2\end{array}$ & $\begin{array}{l}5.5 \\
1.7 \\
0.6\end{array}$ & $\begin{aligned} & 5 \cdot 3(2 \cdot 3,12 \cdot 6) \\
& 10 \cdot 3(1.4,78 \cdot 8) \\
& 1.7(0.4,7.5)\end{aligned}$ & $\begin{array}{l}26 \cdot 5 \\
24 \cdot 6 \\
42 \cdot 9\end{array}$ & $\begin{array}{l}8 \cdot 9 \\
4 \cdot 0 \\
0 \cdot 7\end{array}$ & $\begin{array}{c}6 \cdot 8(3 \cdot 3,13 \cdot 9) \\
3 \cdot 1(1 \cdot 1,9 \cdot 1) \\
75 \cdot 1(18 \cdot 9,298 \cdot 5)\end{array}$ \\
\hline $\begin{array}{l}\text { Eczema } \\
\text { Hong Kong } \\
\text { Kota Kinabalu } \\
\text { San Bu }\end{array}$ & $\begin{array}{r}22 \cdot 5 \\
7 \cdot 4 \\
10 \cdot 7\end{array}$ & $\begin{array}{r}21 \cdot 0 \\
4 \cdot 3 \\
8 \cdot 8\end{array}$ & $\begin{array}{l}1 \cdot 1(0 \cdot 7,1 \cdot 8) \\
1 \cdot 9(0 \cdot 6,5 \cdot 6) \\
1 \cdot 2(0 \cdot 6,2 \cdot 1)\end{array}$ & $\begin{array}{l}51 \cdot 3 \\
39 \cdot 3 \\
62 \cdot 8\end{array}$ & $\begin{array}{r}10 \cdot 5 \\
4 \cdot 2 \\
7 \cdot 2\end{array}$ & $\begin{array}{c}8 \cdot 5(5 \cdot 2,13 \cdot 9) \\
13 \cdot 7(4 \cdot 6,40 \cdot 8) \\
24 \cdot 1(10 \cdot 8,53 \cdot 7)\end{array}$ \\
\hline
\end{tabular}

*Adjusted for age, sex, atopic status, and family history of the symptom of interest. 
Table 4 Socioeconomic profiles of Hong Kong, Malaysia and China

\begin{tabular}{llll}
\hline & Hong Kong & Malaysia & China \\
\hline Economy (income) & Upper & Upper middle & Low \\
Population (1988) & $5 \cdot 8$ million & $17 \cdot 9$ million & $1 \cdot 1$ billion \\
Urban population (\%) & $92 \cdot 4$ & $38 \cdot 2$ & $20 \cdot 6$ \\
Ethnic groups & $98 \%$ Chinese & $\begin{array}{l}30 \% \text { Chinese } \\
61 \% \text { Malay }\end{array}$ & $\begin{array}{l}93 \% \text { Chinese } \\
\text { (Han) }\end{array}$ \\
& & $8 \%$ Indian & \\
Life expectancy (years) & & 69 & 69 \\
$\quad$ Male & 74 & 73 & 73 \\
Female & 80 & 2340 & 370 \\
GDP per head (US \$) & 11540 & $21 \cdot 9$ & $12 \cdot 1$ \\
GDP with PPP (US =100) & $60 \cdot 4$ & 1283 & 749 \\
Energy consumption (kilos coal & 1891 & 73 & 69 \\
equivalent) & & 24 & 27 \\
Adult literacy (\%) & 85 & $3 \cdot 5$ & $2 \cdot 4$ \\
Infant mortality rate & 8 & 292 & 839 \\
Fertility rate & $1 \cdot 7$ & 195 & 2265 \\
Doctors (no. per million) & 906 & & \\
Cigarettes (per person per year) & 1518 & & \\
\hline
\end{tabular}

$\mathrm{PPP}=$ purchasing power parity. tionnaires. The belief in traditional and herbal medicine is widespread amongst many Chinese families and terms such as "wheeze" or "asthma" may not be used by local practitioners. Moreover, it is recognised that the Chinese believe that chronic illnesses exert global effects on physical and spiritual aspects of the present as well as future life; this concept could possibly result in denial of symptoms and different diagnostic labels may be more acceptable to the parents. ${ }^{24}$ In contrast, Hong Kong has a westernised lifestyle and a higher standard of living and education. The community as a whole is likely to be more informed and therefore more aware of asthma and allergy symptoms in China. Zhong et al studied 3067 students aged 11-17 years in rural and urban Guangdong, a short distance from San $\mathrm{Bu}$, using questionnaire, skin test and bronchial hyperreactivity assessment, and found an asthma prevalence of $2 \cdot 4 \%{ }^{8}$ Previous studies in Hong Kong have shown that asthma was present in $7 \cdot 3-10 \%$ of schoolchildren between the age of seven and 15 years. ${ }^{1325}$ These prevalence estimates are consistent with our results, indicating that other explanations besides awareness of symptoms are needed for the difference in prevalence between the three south-east Asian populations.

Exposure to high levels of air pollutants including sulphur dioxide, nitrogen dioxide, ozone, and suspended particulates has long been implicated as a possible cause of respiratory morbidity. ${ }^{2627}$ Whilst the concentrations of these pollutants in the atmosphere have been under more stringent control in many developed countries in recent years, the prevalence of asthma and allergic rhinitis has not, in fact, shown a reducing trend but has risen to a higher level. In contrast, many developing countries in Asia are generally more polluted and yet retain a low prevalence of these conditions. Data from the United Nation Environmental Program showed that the annual mean level of ambient sulphur dioxide concentration was $0.012(0.002-0.035) \mathrm{ppm}$ for Hong Kong and 0.006 (0.001-0.015) ppm for Kuala Lumpur between 1973 and 1980, and was $0.024 \mathrm{ppm}$ for Guangzhou between 1982 and $1984 .^{28} 29$ There is no available information on atmospheric pollution for Kota Kinabalu and San Bu which, being less populated with light industrial activities than Kuala Lumpur and Guangzhou respectively, would be expected to have lower levels of sulphur dioxide and other ambient pollutants in the atmosphere. The upper level of ambient sulphur dioxide concentration recommended by WHO is $0.017 \mathrm{ppm}$ and, ironically, heavily polluted areas such as Guangzhou has one of the lowest prevalences of childhood asthma in the world. ${ }^{8}$

Passive smoking increases the risk of childhood asthma, ${ }^{30}$ the frequency of asthmatic attacks, ${ }^{31}$ and its adverse effect is dose-related. ${ }^{30}$ Decrease in asthma severity with cessation of maternal smoking has been documented. ${ }^{32}$ Cigarette smoke increases both bronchial reactivity ${ }^{33}$ and permeability ${ }^{35}$ which, in turn, allows influx of allergens across the bronchial economic profiles between Hong Kong a, and China as shown in table 4 . In from rural areas and farming communities where the literacy rate is low and they may have had difficulty in comprehending the ques- 
mucosa resulting in raised IgE levels often found in children of smoking parents. ${ }^{36} \mathrm{Un}$ fortunately parental smoking and active smoking in the students was not examined in the study. Cigarette consumption is high in China (table 4) and it is possible that a significant proportion of students in San Bu and their parents were active smokers. Nevertheless, the prevalence of asthma and allergic disease was the lowest in the three populations suggesting that the adverse effect of cigarrette smoke could be counterbalanced by other more significant protective factors.

House dust mite is the most important indoor allergen which has been associated with asthma and bronchial hyperreactivity in many parts of the world including south-east Asia. ${ }^{37-39}$ Many homes in South China and Hong Kong ${ }^{38}$ are heavily infested with dust mite ${ }^{40}$ and repeated exposure to mite allergens is important for the clinical expression of asthma in mite sensitive individuals. ${ }^{41}$ Cockroach hypersensitivity has been recognised as a risk factor for asthma, particularly amongst lower socioeconomic groups in crowded multi-family dwellings. ${ }^{42}$ Dust mite and cockroach sensitivity was common and the rate of sensitisation to these allergens was comparable between the three populations, suggesting that the disagreement in the prevalence of asthma and allergic disease could not be adequately explained by specific aeroallergen sensitisation. We used pollen extracts of cool temperate grasses in skin testing but, despite being common causes of hayfever elsewhere, these grasses are only found in small quantities in parts of south-east Asia with a subtropical climate. The low prevalence of pollen sensitivity and hayfever in the three populations is likely to be related to limited exposure to grass pollen. Indeed, hayfever in China has been linked to other pollens including castor bean, plane tree, and sagebrush. ${ }^{43}$

Students in Hong Kong had a more severe degree of reactivity and higher prevalence of asthma and allergic disease than students in Kota Kinabalu and San Bu. The degree of reactivity has previously been associated with the occurrence of respiratory symptoms ${ }^{16}$ and severity of both asthma ${ }^{44}$ and bronchial hyperresponsiveness. ${ }^{816}$ We found a close association between the relative odds for wheeze and asthma and the degree of reactivity, but such relationship was seen in all three populations (data not shown), implying that the difference in prevalence between the three populations could not be explained by the degree of reactivity to common inhalant allergens.

Family history was the factor with the strongest association with asthma and allergic symptoms, conferring a 3-80-fold increase in risk to family members which is significantly higher than the 2-3-fold increase found for Western countries. ${ }^{456}$ Despite the familial tendency the prevalence is low, indicating that any hypothesised factors common to the family, although strong, are relatively rare. The basis for the strong association between family members of aetiological factors for asthma and allergic disease in the three south-east Asian pop- ulations is unclear. A possible reason for this familial association is reporting bias which may be amplified in uncommon conditions. As questionnaires were completed by the parents, it is possible that the parents' report of asthma and allergy in the students was biased by their own history. Unfortunately the design of our study did not allow an assessment of the extent of false reporting. Alternatively, common genetic and/or environmental factors in the family could interact in a complex manner to initiate clinical asthma and allergy. The inheritance of $\mathrm{IgE}$ responsiveness has been linked to the gene locus of chromosome $11 \mathrm{q} 13$ but this has not been found amongst Chinese populations. ${ }^{47}$ Although HLA-BW61 haplotype has been associated with a 6.6 times risk for asthma in Northern Chinese in one study, ${ }^{48}$ others found no evidence of HLA involvement in the expression of clinical asthma. ${ }^{49} 50$ Recent twin studies showed that $40-50 \%$ of the variation of the liability for asthma and hayfever cannot be accounted for by genetic factors, suggesting the importance of environment factors in determining the occurrence of these conditions. ${ }^{51}$ The pathogenetic role of environmental adjuvants including susceptibility to certain viral infections, the indoor microclimate that may facilitate the growth of dust mite and other indoor allergens, dietary factors, and others is unknown and deserves further investigation.

We found that the prevalence of asthma and allergic disease in school students is low but is different between Hong Kong, Kota Kinabalu and $\mathrm{San} \mathrm{Bu}$ despite similar atopy rates. The difference in prevalence could not be solely explained by difference in sensitisation to aeroallergens and awareness of symptoms. The three populations differ in many aspects of socioeconomic profiles and these characteristics may be important and need to be explored further in future comparative studies. Family history is the strongest predictor for asthma and allergic disease in the students, suggesting the existence of important pathogenetic factors that are common to the family.

1 Clifford RD, Howell JB, Radford M, Holgate ST. Associations between respiratory symptoms, bronchial response to methacholine and atopy in two age groups of schoolchildren. Arch Dis Child 1989;64:1133-9.

2 Jones DT, Sears MR, Holdsway MD, Hewitt CJ, Flannery EM, Herbison GP, et al. Childhood asthma in New Zealand. $B r \mathcal{F}$ Dis Chest 1987;81:332-40.

3 Robertson CF, Heycock E, Bishop J, Nolan T, Olinsky A, Phelan PD. Prevalence of asthma in Melbourne schoolchildren: change over 26 years. BMF 1991;302:1116-8.

4 Burr ML, Butland BK, King S, Vaughan-Williams E. Changes in asthma prevalence: two surveys 15 years apart. Arch Dis Child 1989;64:1452-6.

5 Ninan TK, Russell G. Respiratory symptoms and atopy in Aberdeen schoolchildren: evidence from two surveys 25 years apart. $B M \mathcal{F} 1992 ; 304: 873-5$.

6 Peat JK, Haby M, Spijker J, Berry G, Woolcock AJ. Prevalence of asthma in adults in Busselton, Western Australia. $B M \mathcal{F}$ 1992;305:1326-9.

7 Omar AH. Respiratory symptoms and asthma in primary school children in Kuala Lumpur. Acta Paediatr fpn 1990; 32:183-7.

8 Zhong NS, Chen RC, O-yang M, Wu JY, Fu WX, Shi LJ. Bronchial hyperresponsiveness in young students of southern China: relation to respiratory symptoms, diagnosed asthma, and risk factors. Thorax 1991;45:860-5.

9 Leung R. Allergy and atopy in Hong Kong - a review. $f$ Hong Kong Med Assoc 1993;45:234-40.

10 Leung R, Jenkins M. Prevalence of asthma and allergic diseases in Southern Chinese schoolchildren. Clin Exp Allergy 1994;24:353-8.

11 Hsieh KH, Shen JJ. Prevalence of childhood asthma in Taipei, Taiwan, and other Asian Pacific countries. $\mathcal{f}$ Asthma 1988;25:73-82. 
12 Samet JM. A historical and epidemiologic perspective on respiratory symptoms questionnaires. Am $\mathcal{F}$ Epidemiol 1978;108:435-6.

13 Abramson M, Kutin J, Bowes $G$. The prevalence of asthma in Victoria adults. Aust $N Z \mathcal{F}$ Med 1992;22:358-63.

14 Leung R, Tseng RYM. Allergic diseases in Hong Kong schoolchildren. Hong Kong Practitioner 1993;15:2409-20.

15 Pepys J. Skin tests in diagnosis. In: Gell PGH, Coomb PPA, Lachmann PI, eds. Clinical aspects of immumology. 3rd edn. Oxford: Blackwell Scientific Publications, 1975: $55-80$.

16 Peat JK, Britton WJ, Salome CM, Woolcock AJ. Bronchial hyperresponsiveness in two populations of Australian schoolchildren. III. Effect of exposure to environmental allergens. Clin Allergy 1987;17:291-300.

17 Public Health Service, Center for Disease Control. Epilnfo computer program for epidemiology. US Department of Public Health and Human Services, Atlanta, 1990

18 EGRET reference manual. SERC, Seattle, 1989

19 Burney P, Chinn S. Developing a new questionnaire for measuring the prevalence and distribution of asthma. Chest 1987;91:79-83S

20 Josephs LK, Gregg I, Mullee MA, Holgate ST. Nonspecific bronchial reactivity and its relationship to the clinical expression of asthma. Am Rev Respir Dis 1989;140:350-7.

21 World Development Report. World Bank, Oxford University Press, 1992.

22 Salome CM, Peat JK, Britton EJ, Woolcock AJ. Bronchial hyperresponsiveness in two populations of Australian schoolchildren. I. Relation to respiratory symptoms and diagnosed asthma. Clin Allergy 1987;17:271-81.

23 Johnston SL, Clough JB, Pattenmore PK, Smith S, Holgate ST. Longitudinal changes in skin-prick test reactivity over 2 years in a population of schoolchildren with respiratory symptoms. Clin Exp Allergy 1992;22:948-57.

24 Elfert H, Anderson JM, Lai M. Parents' perceptions of children with chronic illness: a study of immigrant families. f Paediatr Nurs 1991;6:114-20.

25 Ong SG, Lui J, Tam YC. Studies on respiratory health of primary school children in urban communities of Hong Kong. The Science of the total environment 1991;106:12135 .

26 Abramson MJ, Voigt T. Ambient air pollution and respiratory disease. Med $\mathcal{f}$ Aust 1991;154:543-53.

27 Utell MJ, Samet JM. Particulate air pollution and health; new evidence on an old problem. Am Rev Respir Dis 1993 147:1334-5.

28 UNEP Environmental Data Report. United Nations Environmental Programs. Oxford: Blackwell, 1987.

29 UNEP Environmental Data Report. United Nations Environmental Programs. Oxford: Blackwell, 1991.

30 Kershaw CR. Passive smoking, potential atopy and asthma in the first five years. $7 R$ Soc Med 1987;80:663-87.

31 Evans D, Levison MJ, Feldman CH, Clark NM, Wasilewski $\mathrm{Y}$, Levin $\mathrm{B}$, et al. The impact of passive smoking on emergency room visits of urban children with asthma. $\mathrm{Am}$ Rev Respir Dis 1987:135.567-72.

32 Murray AB, Morrison BJ. The decrease in severity of asthma in children of parents who smoke since the parents have been exposing them to less cigarette smoke. $\mathcal{f}$ Allengy Clin Immunol 1993;91:101-10.
33 Gerrard JW, Cockcroft DW, Mink JT, Cotton DJ, Poonawala $R$, Dosman JA. Increased non-specific bronchial reactivity in cigarette smokers with normal lung function. Am Rev Respir Dis 1980;122:577-81.

34 O'Connor GT, Weiss ST, Tager IB, Speizer FE. The effect of passive smoking on pulmonary function and nonspecific bronchial responsiveness in a population based sample of children and young adults. Am Rev Respir Dis 1987;135: $800-4$.

35 Kennedy SM, Elwood RK, Wiggs BJR, Pare PD, Hogg JC. Increased airway mucosal permeability of smokers. $A m$ Rev Respir Dis 1984;129:143-8.

36 Kjellman NIM. Effect of parental smoking on IgE levels in children. Lancet 1981;i:993.

37 Chien YK, Yang WP, Xue ZL, Massey D. House dust mit asthma in China: a review. Ann Allergy 1987;59:147-8.

38 Gabriel M, Cunnington AM, Allan WGL, Pickering CAC, Wraith DG. Mite allergy in Hong Kong. Clin Allengy 1982; 12:157-71.

$39 \mathrm{Hsieh} \mathrm{KH}$. A study of intracutaneous skin tests and radioallergosorbant tests on 1000 asthmatic children in Taiwan. Asian Pac $\mathcal{f}$ Allergy Immunol 1984;2:56-60.

40 Lai NK, Chen SY, He ZN, Chen LJ, O-Yang M, Dai HY, et al. Study of dust mite allergy in the Guangzhou area. Chinese $\mathcal{F}$ Prevent Med 1988;22:347-9.

41 Sporik R, Platts-Mills TAE, Cogswell JJ. Exposure and sensitisation of children admitted to hospital with asthm to house dust mite allergen (Der p I). $\mathbf{f}$ Allergy Clin Immunol 1991;87:1,291

42 Gelber LE, Seltzer LH, Bouzoukis JK, Pollart SM, Chapman MD, Platts-Mills TAE. Sensitisation and exposure to indoor allergens as risk factors for asthma among posure to indoor allergens as risk factors for asthma among patients prese

43 Yeh ST. Present status of clinical allergy in China. Immunol Allerg Prac 1982;4:51-6.

44 McNicol, Williams HE. Spectrum of asthma in children II. Allergic components. $B M F$ 1973;197:12-9.

45 Sherman CB, Tostenson TD, Tager IB, Speizer FE, Weiss S. Early childhood predictors of asthma. $A m \mathcal{F}$ Epidemiol 1990;132:83-8.

46 Jenkins MA, Hopper JL, Giles GG. A population based family study of asthma. Proceedings of Thirteenth Scientific family study of asthma. Proceedings of Thirteenth Scientific Meetin.

47 Cookson WOCM, Faux JA, Sharp PA, Hopkin JM. Linkage between immunoglobulin $\mathrm{E}$ responses underlying asthm and rhinitis and chromosome 11q. Lancet 1989;i:1292-4.

48 Wang WX, Yang SZ, Chui XW, Zhang HL. Association of HLA-BW61 with asthma in the Chinese. Tissue Antigen 1988;32:215-7

49 Turton CWG, Morris L, Buckingham JA, Lawler SD, Turner-Warwick $M$. Histocompatibility antigens in asthma: population and family studies. Thorax 1979;34: 670-6.

50 Morris MJ, Faux JA, Ting A, Morris PJ, Lane DJ. HLA-A, $B$ and $C$ and HLA-DR antigens in intrinsic and allergic asthma. Clin Allergy 1980;10:173-9.

51 Duffy DL, Martin NG, Battistutta D, Hopper JL, Matthews JD. Genetics of asthma and hayfever in Australian twins. Am Rev Respir Dis 1990;142:1351-8. 